Prepared for the U.S. Department of Energy

under Contract DE-AC05-76RL01830

\title{
Effects of Humidity on Solid Oxide Fuel Cell Cathodes
}

John Hardy and Jeff Stevenson

Pacific Northwest National Laboratory

Prabhakar Singh and Manoj Mahapatra

University of Connecticut

Eric Wachsman

University of Maryland

Meilin Liu

Georgia Institute of Technology

Kirk Gerdes

National Energy Technology Laboratory

March 17, 2015 


\title{
DISCLAIMER
}

This report was prepared as an account of work sponsored by an agency of the United States Government. Neither the United States Government nor any agency thereof, nor Battelle Memorial Institute, nor any of their employees, makes any warranty, express or implied, or assumes any legal liability or responsibility for the accuracy, completeness, or usefulness of any information, apparatus, product, or process disclosed, or represents that its use would not infringe privately owned rights. Reference herein to any specific commercial product, process, or service by trade name, trademark, manufacturer, or otherwise does not necessarily constitute or imply its endorsement, recommendation, or favoring by the United States Government or any agency thereof, or Battelle Memorial Institute. The views and opinions of authors expressed herein do not necessarily state or reflect those of the United States Government or any agency thereof.

\author{
PACIFIC NORTHWEST NATIONAL LABORATORY \\ operated by \\ BATTELLE \\ for the \\ UNITED STATES DEPARTMENT OF ENERGY \\ under Contract DE-AC05-76RL01830
}

Printed in the United States of America
Available to DOE and DOE contractors from the Office of Scientific and Technical Information,
P.O. Box 62, Oak Ridge, TN 37831-0062;
ph: (865) 576-8401
fax: $(865)$ 576-5728
email: reports@adonis.osti.gov

\begin{abstract}
Available to the public from the National Technical Information Service, U.S. Department of Commerce, 5285 Port Royal Rd., Springfield, VA 22161 ph: (800) 553-6847 fax: $(703) 605-6900$ email: orders@ntis.fedworld.gov online ordering: http://www.ntis.gov/ordering.htm
\end{abstract}

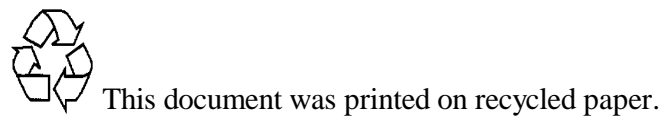




\section{Table of Contents}

Executive Summary $\quad 2$

Introduction $\quad 3$

Experimental Results

1. Effects of Humidity on Cathode Performance 3

1.1 LSM/YSZ Cathodes 3

1.2 LSCF Cathodes 3

2. Effects of Humidity on Cathode Stability 4

2.1 LSM/YSZ Cathodes 4

2.2 LSCF Cathodes 5

3. Operational Parameter Interactions that Influence Humidity Effects 5

4. Mechanisms 6

4.1 Adsorption $\quad 6$

4.2 Role of Humidity in Oxygen Reduction Reactions (ORR) 6

5. Effects of Humidity on Cathode Chemistry and Phase Composition 7

$\begin{array}{ll}5.1 \mathrm{LSM} / \mathrm{YSZ} & 7\end{array}$

5.2 LSCF 8

6. Moisture-induced Changes in Microstructure/Morphology 8

$\begin{array}{lll}6.1 \mathrm{LSM} / \mathrm{YSZ} & 8\end{array}$

6.2 LSCF 9

7. Mitigation Strategies 9

7.1 LSM/YSZ 9

$\begin{array}{ll}7.2 \mathrm{LSCF} & 9\end{array}$

$\begin{array}{ll}\text { Conclusions } & 10\end{array}$

Acknowledgements 11

Figures $\quad 12$ 


\section{Executive Summary}

This report summarizes results from experimental studies performed by a team of researchers assembled on behalf of the Solid-state Energy Conversion Alliance (SECA) Core Technology Program. Team participants employed a variety of techniques to evaluate and mitigate the effects of humidity in solid oxide fuel cell (SOFC) cathode air streams on cathode chemistry, microstructure, and electrochemical performance.

Overall, there was a considerable degree of concurrence in the experimental results. Primary conclusions from the work are:

- Humidity in cathode air can cause an immediate increase in the polarization resistance of LSM/YSZ cathodes; this effect is reversible when the humidity is removed.

- Humidity in cathode air can produce an increase in the LSM/YSZ cathode performance degradation rate, with the effect being more pronounced at higher current densities.

- Chemical effects of humidity on LSM/YSZ cathodes can include Mn interdiffusion, Mnoxide formation at the LSM-YSZ interfaces, Mn enrichment at the YSZ grain boundaries, and expansion of LSM lattice parameters.

- Humidity in the cathode air can cause an increase in the polarization resistance of LSCF cathodes; the effect is more pronounced at lower temperatures.

- Humidity in the cathode air can cause an increased degradation rate in LSCF at temperatures below $700-750^{\circ} \mathrm{C}$, but can result in a decreased degradation rate at higher temperatures.

- Humidity can lead to increased Sr or Co segregation in LSCF cathodes as well as an increased rate of compositional evolution of minor iron cobalt spinel phases

- Infiltration is a possible means of mitigating the effects of humidity on LSM/YSZ and LSCF cathodes. 


\section{Introduction}

Recently, a team of R\&D participants in the Core Technology Program of the Solid-state Energy Conversion Alliance (SECA) were assembled to perform a variety of studies intended to evaluate and mitigate the effects of humidity in solid oxide fuel cell (SOFC) cathode air streams on cathode chemistry, microstructure, and electrochemical performance. This report briefly summarizes the primary results of the studies. Note that, unless otherwise noted, LSM and LSCF represent the complex perovskite oxides $\mathrm{La}_{0.8} \mathrm{Sr}_{0.2} \mathrm{MnO}_{3}$ and $\mathrm{La}_{0.6} \mathrm{Sr}_{0.4} \mathrm{Co}_{0.2} \mathrm{Fe}_{0.8} \mathrm{O}_{3}$, respectively.

\section{Experimental Results}

\section{Effects of Humidity on Cathode Performance}

\subsection{LSM/YSZ Cathodes}

In electrical tests performed at the University of Connecticut on single LSM/YSZ cell stacks at $800 \mathrm{C}$, little to no immediate influence on I-V characteristics was observed when $3 \%$ water was added to the cathode air as shown in Figure 1. Button cell tests conducted for $\sim 1000$ hours at PNNL in which the water content of the cathode air was alternated between $0 \%$ and $3 \%$ every $\sim 250$ hours revealed that, at temperatures below $900^{\circ} \mathrm{C}$, a step change in ASR occurred when the humidity level was changed in either direction. This is shown in Figure 2, in which the periods of exposure to humid air are shaded in blue. Similarly, the University of Connecticut found that when the LSM/YSZ cathode was exposed to air with an increased water content of $20 \%$ during testing at $850^{\circ} \mathrm{C}$ and $0.5 \mathrm{~V}$ bias, there was an immediate increase in polarization resistance that was reversible when the humidified cathode air was replaced by dry air, as shown in Figure 3.

\subsection{LSCF Cathodes}

Georgia Institute of Technology found that the interfacial polarization resistance of LSCF varied as a function of water vapor content in the cathode air under open circuit voltage (OCV) conditions at $750^{\circ} \mathrm{C}$. As shown in Figure 4, an increase in polarization resistance occurred at a water concentration of 3\%, and gradually increased with increasing water vapor concentration.

When Georgia Institute of Technology exposed the LSCF cathode to a variety of water vapor concentrations at $600^{\circ} \mathrm{C}$, it exhibited a different electrochemical behavior with regards to polarization resistance. At this temperature, polarization resistance increased significantly when $3 \%$ water vapor was added to the cathode air (Figure 5). However, further increases in water content had little effect, suggesting that the adsorption of water vapor preferentially occupied the active sites of the LSCF surface and that at lower temperature full coverage is more likely to be reached at lower concentrations of water vapor. When a cathodic polarization current of 500 $\mathrm{mAcm}^{-2}$ was applied, the polarization of an LSCF cell also increased with elevated water vapor concentration but the change in polarization resistance was smaller than at OCV (Figure 6). 
The effects of humidity on LSCF cathode performance at various temperatures and water vapor concentrations observed by Georgia Institute of Technology are summarized in Table I and Figure 7. The change in polarization resistance did not depend linearly on the concentration of water vapor in the range studied. It appears that there was a saturation concentration beyond which the increase in water concentration has little effect. The degree of polarization resistance increase at $10 \%$ water vapor did not show significant temperature dependence. However, at lower water vapor concentration, the polarization resistance increase was larger at the lower temperature.

Table I. The percent increase in polarization resistance of the LSCF cathode when exposed to different concentrations of water vapor at 600 and $750^{\circ} \mathrm{C}$ (Georgia Institute of Technology).

\begin{tabular}{|c|c|c|c|}
\hline \multirow{2}{*}{ Temperature } & \multicolumn{3}{|c|}{ Water vapor concentration (\%) } \\
\cline { 2 - 4 } & $\mathbf{3} \% \mathbf{H}_{\mathbf{2}} \mathbf{O}$ & $\mathbf{5 \%} \mathbf{H}_{\mathbf{2}} \mathbf{O}$ & $\mathbf{1 0} \% \mathbf{H}_{\mathbf{2}} \mathbf{O}$ \\
\hline $\mathbf{6 0 0}{ }^{\circ} \mathrm{C}$ & $7.1 \%$ & $8.4 \%$ & $8.7 \%$ \\
\hline $\mathbf{7 5 0} 0^{\circ} \mathrm{C}$ & $1.9 \%$ & $5.4 \%$ & $8.5 \%$ \\
\hline
\end{tabular}

To verify the relationship between LSCF and water vapor indicated by isotopic exchange studies (see below), University of Maryland researchers performed EIS measurements on LSCF-GDC symmetrical cells. The results demonstrated an increase in low frequency polarization resistance at $450^{\circ} \mathrm{C}$ when exposed to humid air, but no significant effect of water at $750^{\circ} \mathrm{C}$ (Figure 8), which was indeed consistent with the temperature region of water exchange with LSCF determined by isotope exchange.

Georgia Institute of Technology also found that the small effect of humidity on LSCF cathode performance was reversible under both OCV and ordinary operating conditions at 600 and $750^{\circ} \mathrm{C}$. As shown in Figure 9 and 10, the polarization resistance of LSCF cells increased slightly when the water vapor concentration was increased from 0 to $10 \%$ and was reversible when the gas was switched to dry air (with $10 \%$ argon) from wet air (with $10 \%$ water vapor) within a short period of time. However, with additional exposures to humid air at $600^{\circ} \mathrm{C}$, it took a progressively longer time to recover, implying possible reconstruction on the surface of the LSCF cathode when exposed to humidity at low temperatures (Figure 10).

\section{Effects of Humidity on Cathode Stability}

\subsection{LSM/YSZ Cathodes}

Multiple $\sim 1000$ hour tests at various temperatures between 800 and $950^{\circ} \mathrm{C}$ at PNNL found that LSM/YSZ cells tested in cathode air containing 3\% water degraded faster than cells tested in dry air when the temperature was below $950^{\circ} \mathrm{C}$. Additionally, when cells were exposed to cathode air that was switched between $0 \%$ and $3 \%$ water vapor every 250 hours, degradation was faster 
during exposure to moist air at all temperatures including $950^{\circ} \mathrm{C}$. As shown in Figure 2, it was also found that the degradation was at least partially reversible when switched back to dry air, with reversibility increasing as temperature decreased. At the University of Connecticut, it was found that $3 \%$ moisture in air degraded LSM/YSZ cathode performance at $750-850^{\circ} \mathrm{C}$ due to the segregation of $\mathrm{SrO} / \mathrm{Sr}(\mathrm{OH})_{2}$ at the LSM surface (Figure 11). $\mathrm{La}_{2} \mathrm{Zr}_{2} \mathrm{O}_{7}$ and $\mathrm{MnO}_{\mathrm{x}}$ formation at the LSM-YSZ interface was also observed. LSM/YSZ cells in which the Sr-content of the LSM was decreased from the typical $20 \%$ to 0 and $5 \%$ of the A-site were also tested for $\sim 1000 \mathrm{~h}$ at PNNL. In these tests, it was found that there was no significant difference in the effects of humidity on degradation compared to the effects on cathodes with the typical $20 \%$ Sr-doped LSM composition.

EIS data from the University of Maryland on LSM-YSZ/YSZ/LSM-YSZ symmetrical cells aged for 400 hours indicated that degradation could be divided into three different time periods: (1) growth of the second arc, (2) shrinking of the second arc, and (3) finally a shifting of series resistance. Results at the National Energy Technology Laboratory (NETL) agreed with those at University of Maryland, indicating that both polarization and ohmic resistances of LSM cells increase over time. In their tests, LSM was susceptible to water to a degree that depended on the applied current density (cell overpotential). In general, the LSM appeared stable in up to $10 \%$ water at a current density of $0.25 \mathrm{~A} / \mathrm{cm}^{2}$ as shown in Figure 12, but exhibited significant instability in $10 \%$ water at current density of $0.75 \mathrm{~A} / \mathrm{cm}^{2}$, as shown in Figure 13 . Also, exposure to $20 \%$ water, even at the lower current density, caused significant degradation.

\subsection{LSCF Cathodes}

In tests similar to those they performed on LSM/YSZ cathodes, PNNL found that temperature also plays a role in the effects of humidity on degradation of LSCF cathodes. In the case of LSCF, adding $3 \%$ water to the cathode air increased the degradation rates of cells operated at lower temperatures and decreased the degradation rate of cells operated at higher temperatures, with the transition temperature lying in the $700-750^{\circ} \mathrm{C}$ range. During short term tests carried out for 30 hours at $750^{\circ} \mathrm{C}$ at Georgia Institute of Technology, the performance of cells with LSCF cathodes was relatively stable during exposure to humid air for 30 hours of testing at a constant cell voltage (see Figure 14).

\section{Operational Parameter Interactions that Influence Humidity Effects}

Tests performed by various researchers within the SECA program indicated that in addition to simple single parameter effects such as the temperature effects on degradation, there are also interactions between multiple operational parameters that influence the effect humidity has on SOFC cathodes. For example, as discussed previously in relation to Table I, the Georgia Institute of Technology found that the effect of different concentrations of water vapor on LSCF cathode performance depended on the SOFC operation temperature. 
Also, as previously pointed out when discussing the work by NETL, there is also an interaction between the current density and humidity level that plays a role in the humidity effect on LSMbased cathodes. The effect of different concentrations of water vapor on the degradation rate depended on the current density at which the cell was operated. A literature survey performed by PNNL looking at the results of humidity studies on LSM-based cells conducted by researchers outside of the SECA program in conjunction with the results reported by SECA participants corroborated NETL's findings and found that degradation in $3-10 \%$ water vapor may only become evident when the current density is greater than $\sim 250-400 \mathrm{~mA} / \mathrm{cm}^{2}$.

The two-parameter interactions described above point to the fact that there is likely a threeparameter interaction between temperature, current density, and water concentration that could potentially be mapped out with a parametric study.

\section{Mechanisms}

\subsection{Adsorption}

Results at the Georgia Institute of Technology suggest that water molecules may adsorb on the surface of LSCF. The performance change in LSCF cathodes seems to be more sensitive to the increase in concentration of contaminants at $600^{\circ} \mathrm{C}$ than at $750^{\circ} \mathrm{C}$. However, the maximum performance degradation appears to be independent of temperature, suggesting that the adsorption of water on LSCF is more favorable at low temperature while the total adsorption capacity of the LSCF cathode surface is independent of temperature. The adsorbed water may then react with segregated/enriched Sr or Co to form hydroxide. Sr or Co segregation is then exacerbated by the presence of water, which they hypothesize could be the main cause of long term degradation.

At the University of Maryland, a competitive adsorption/desorption process between $\mathrm{O}_{2}$ and water on both LSCF and LSM-based cathode surfaces was observed, and the dominant regions of each gas at different temperatures and concentrations was mapped out.

Work on LSM/YSZ cathodes at the University of Connecticut indicated that inter-diffusion of Mn between the LSM and YSZ phases is likely the origin of the destabilization. This may be enhanced by the presence of adsorbed surface $\mathrm{OH}$ provided by humid atmospheres, which might allow some local charge transfer that would facilitate the interdiffusion process.

\subsection{Role of Humidity in Oxygen Reduction Reaction (ORR)}

The isotopic exchange work at the University of Maryland determined that water participates in the ORR of both LSCF and LSM-based cathodes. Surface oxygen exchange with water is preferred in different temperature ranges. Water starts to exchange with LSM and LSCF at around $300-400^{\circ} \mathrm{C}$ and has a greater influence at lower temperature for LSCF than LSM, with 
strong water exchange peaks at $300^{\circ} \mathrm{C}$ and $450^{\circ} \mathrm{C}$. The regions in temperature, $\mathrm{pO}_{2}$, and $\mathrm{pH}_{2} \mathrm{O}$ where $\mathrm{H}_{2} \mathrm{O}$ vs $\mathrm{O}_{2}$ exchange dominate for LSM and LSCF are shown in Figure 15. Additionally, it was observed that LSCF-GDC and LSM-YSZ composite materials show different exchange mechanisms and the presence of YSZ dramatically increases the water exchange in LSM-YSZ composites relative to single phase LSM and shifts it to lower temperatures.

\section{Effects of Humidity on Cathode Chemistry and Phase Composition}

\subsection{LSM/YSZ}

As discussed earlier, University of Connecticut researchers found that interdiffusion of Mn may be enhanced by moisture due to surface $\mathrm{OH}$. They also observed $\mathrm{MnO}_{\mathrm{x}}$ formation at the LSMYSZ interface and pointed out that $\mathrm{Sr}$ segregation was the source of performance degradation. $\mathrm{XRD}$ analysis found that moisture retards or eliminates the formation of $\mathrm{La}_{2} \mathrm{Zr}_{2} \mathrm{O}_{7}$ in LSM-YSZ.

In-operando XRD was performed on LSM/YSZ-based cells at PNNL while the cells were exposed to humid and dry cathode air at $775^{\circ} \mathrm{C}$ and $\sim 0.8 \mathrm{~V}$. The cell tested in dry air showed higher, more stable performance than the cell tested in air containing 3\% water, as shown in Figure 16a. Rietveld refinement of XRD patterns resulting from summation of spectra collected over hundreds of hours indicated that 3\% moisture caused expansion in the LSM crystal lattice as a function of time during cell operation as shown in Figure 16b, as opposed to an apparent contraction of the lattice which occurred at a slower, decaying rate in dry air. Such lattice strain is typically caused by a change in stoichiometry or ionic substitution. While the specific cause of the observed changes in unit cell volume are not yet known, LSM unit cell volume is directly related to La-content and inversely related to $\mathrm{Sr}$ and $\mathrm{O}$ contents, which would support the claim by the University of Connecticut that degradation correlates to $\mathrm{Sr}$ segregation. XRD also found that $\mathrm{La}_{2} \mathrm{O}_{3}$ and $\mathrm{Mn}$-oxides were present in the cathode in quantities of less than $4 \mathrm{wt} \%$. Additionally, less than $1 \%$ tetragonal $\mathrm{YSZ}$ was present as well as trace amounts of $\mathrm{La}_{2} \mathrm{Zr}_{2} \mathrm{O}_{7}$. All of these minor phases were present from the beginning to the end of testing in concentrations that did not vary significantly over the course of the test. It is therefore believed that these phases formed during sintering.

Among LSM-YSZ/YSZ/LSM-YSZ symmetrical cells aged at the University of Maryland for 400 hours, a sample exposed to humidity appeared to have volume phase fractions that differed from the source materials, as well as greater variance than the unaged sample as a function of distance from the bulk electrolyte. Post FIB-SEM and TEM results found that significant segregation of $\mathrm{La}$ and Mn to the YSZ grain boundaries was observed in only the cathodically polarized sample that was exposed to humid air (Figure 17). Sr was not observed to migrate in the same manner. 


\subsection{LSCF}

As discussed previously, results from the Georgia Institute of Technology suggest that water adsorption may exacerbate $\mathrm{Sr}$ or Co segregation/enrichment because the presence of water promotes the formation of A-site deficiency. Based on their synchrotron-enabled XAS and XPS results, adsorbed species may bond to $\mathrm{Co}$ and $\mathrm{Fe}$, and thus affect the valence of $\mathrm{Co}$ and $\mathrm{Fe}$ (more so with $\mathrm{Co}$ than $\mathrm{Fe}$ ) which can be correlated with the temperature dependence of electrochemical results (see Figure 18). This implies that the bonding of water with Co on the surface of the LSCF cathode may reduce the surface oxygen vacancy concentration, and also impede the transport of oxygen species from the adsorption/dissociation sites to other active sites. These might be the main reasons for the observed reversible change in performance.

In-operando XRD performed at $700^{\circ} \mathrm{C}$ at PNNL found that the presence of $3 \%$ water in the cathode air caused the lattice of a minor Fe-rich iron cobalt spinel phase that was present at a concentration of less than $1.5 \mathrm{wt} \%$ in the LSCF cathode to expand more quickly than it did under the same conditions in dry air as shown in the Rietveld refinement results plotted in Figure 19. In addition, the lattice of a Co-rich iron cobalt spinel that was also present in concentrations of less than $2 \mathrm{wt} \%$ did not contract in humid air as it had in dry air. The lattice parameter of iron cobalt spinel is directly related to the $\mathrm{Fe} / \mathrm{Co}$ ratio, meaning that humid air caused the $\mathrm{Fe}$ content to increase more quickly in the Fe-rich spinel and not to decrease in the Co-rich spinel. This indicates that $\mathrm{Fe}$ and $\mathrm{Co}$ ions are mobile in the cathode with interdiffusion and exchange occurring between LSCF and the spinel. It appears as if humidity influences the relative mobilities of Fe and Co.

\section{Moisture-induced Changes in Microstructure/Morphology}

\subsection{LSM/YSZ}

No significant microstructural differences were found in SEM/EDS analysis at PNNL when comparing LSM/YSZ cells that had been tested in dry and moist cathode air for $\sim 1000$ hours. At the University of Maryland, LSM/YSZ cells aged in dry and humid conditions were analyzed with FIB/SEM after operation under anodic and cathodic polarization. In all cells, the YSZ and pore networks were found to be completely percolated, while the LSM particles were more isolated, limiting charge transport. The LSM phase was least connected in the sample aged under cathodic polarization and wet air (Figure 20). Likewise, while there was little difference in the active TPB density ( $\rho$ TPB) between samples aged in dry air with and without polarization, the cathodic sample exposed to moist air was found to have a significantly higher inactive fraction of TPB lengths ( 2:1 active:inactive in dry samples; 1:1 in cathodic samples exposed to moist air). Post FIB-SEM and TEM results indicated that exposure to humid environments caused microstructural coarsening. 


\subsection{LSCF}

In SEM images of fracture surfaces taken at PNNL and shown in Figure 21, nano-nodules were found on the surfaces of LSCF cathodes tested at 650 and $700^{\circ} \mathrm{C}$ for $\sim 1000 \mathrm{~h}$, corresponding to the temperatures at which degradation rates were measured to be higher in the presence of humidity, as discussed in a prior section of this report. The nodules were larger in cells exposed to $3 \%$ water than in cells exposed to dry air. Similar nano-nodules were not present in cells tested at 750 and $800^{\circ} \mathrm{C}$ for the same length of time, corresponding to temperatures at which degradation rates decreased or remained unchanged in the presence of humid air. The chemical composition of these nodules could not be resolved.

\section{Mitigation Strategies}

\subsection{LSM/YSZ}

When NETL added a Mn-based infiltrate to the LSM cathode using a conventional means of infiltration, a significant mitigation in the degradation rate was observed, particularly under conditions that produced an aggressive degradation in a non-infiltrated specimen. Polarization resistance was observed to decrease over time in the infiltrated cells during exposure to moist air, implying that the efficacy of the applied $\mathrm{Mn}$ is in catalyzing the oxygen reduction reaction, and that the catalytic properties are enhanced by the presence of water.

\subsection{LSCF}

Georgia Institute of Technology proposed that the best way to mitigate water-induced LSCF degradation is to prevent strontium segregation. The tendency of strontium segregation could be reduced through surface treatments (such as plasma treatment or proper doping) to alter the activation energy associated with strontium segregation. They also suggested surface modification of the LSCF cathode using electro-catalysts which do not contain strontium or have little tendency for strontium segregation, thus maintaining the high electrocatalytic activity of the LSCF cathode. Another strategy they proposed is to develop more efficient catalysts which minimize the adsorption/absorption of water with which to decorate the surface of the LSCF cathode. They summarized that the most effective catalyst should possess the following properties in comparison with LSCF:

1. Weaker adsorption capability for water both physically and chemically;

2. More robust and stable local structure when bonded with water;

3. The same or better electrocatalytic activity;

4. No negative effect impact on the cathode durability. Their mitigation work to date has focused on developing conformal catalyst coatings based on perovskite-related materials to cover the entire LSCF cathode surface (Figure 22). New catalyst coatings, such as $\operatorname{Pr}_{0.9} \mathrm{MnO}_{3-\delta}(\mathrm{PM}), \mathrm{La}_{0.72} \mathrm{Sr}_{0.18} \mathrm{MnO}_{3-\delta}$ (LSM), and $\mathrm{Pr}_{2} \mathrm{Ni}_{0.5} \mathrm{Mn}_{0.5} \mathrm{O}_{4-\delta}(\mathrm{PNM})$, 
were used by Georgia Institute of Technology to modify the surface of LSCF cathodes, and preliminary results showed that the order of capability for the resistance to water is PM > LSM > $\mathrm{LSCF}>\mathrm{PNM}$ while the order of electrocatalytic activity at OCV is PNM > LSM > PM.

\section{Conclusions}

There was a considerable degree of concurrence in the results of several research teams that employed a variety of techniques to study the effects of humidity on LSM/YSZ cathodes. For example, the University of Connecticut, the University of Maryland, and PNNL agree that humidity caused an immediate increase in the polarization resistance of LSM/YSZ cathodes that was reversible upon reintroducing dry air. At PNNL and the University of Maryland, this was observed in air containing 3\% water, while at the University of Connecticut it was not seen until $20 \%$ water was introduced. This may have been due to different operating parameters or configurations being employed at the various facilities. With regards to moisture effects on LSM/YSZ stability, PNNL, NETL, the University of Maryland, and the University of Connecticut observed increased rates of LSM/YSZ cathode performance degradation in humid air, with humidity affecting both ohmic and polarization resistance. NETL found that there is an interactive effect of current density and humidity levels on the degradation rate. The University of Maryland and the University of Connecticut agree that water adsorption plays a role in the impact humidity has on LSM/YSZ cathodes. In terms of humidity effects on chemical composition, the University of Connecticut observed enhanced Mn and Y interdiffusion in LSM/YSZ cathodes in moist air and Mn-oxide formation at the LSM-YSZ interfaces. They also found that moisture decreases or eliminates the formation of $\mathrm{La}_{2} \mathrm{Zr}_{2} \mathrm{O}_{7}$ and proposed that $\mathrm{Sr}$ segregation was the source of performance degradation. The University of Maryland results concurred that there was Mn enrichment at the YSZ grain boundaries in LSM/YSZ cathodes operated in humid air. There was also La enrichment together with the Mn. PNNL found that the LSM crystal lattice gradually expanded during cathode operation in humid air, which can be caused by $\mathrm{Sr}$ being expelled from the lattice. While they did detect La- and Mn-oxides, $\mathrm{La}_{2} \mathrm{Zr}_{2} \mathrm{O}_{7}$, and tetragonal YSZ in the cathode, they did not find that the overall concentrations of these phases changed significantly over time during cell operation. Microstructurally, no significant differences were found at PNNL when comparing LSM/YSZ cells that had been tested in dry and moist cathode air in SEM. However, using FIB/SEM, the University of Maryland determined that humidity caused the connectivity of the LSM phase to decrease, the inactive fraction of TPB lengths to increase, and the overall microstructure to coarsen.

A similar degree of agreement in results was realized in the study of humidity effects on LSCF cathodes. Georgia Institute of Technology and the University of Maryland agreed that humidity in the cathode air causes an increase in the polarization resistance of LSCF cathodes that is exacerbated at lower temperatures. Georgia Institute of Technology demonstrated that the effect of humidity on LSCF cathode performance was reversible at both 600 and $750^{\circ} \mathrm{C}$. At $600^{\circ} \mathrm{C}$, the time it took to recover from the effects of humidity increased with the number of exposures to 
humid cathode air. They also found that there is an interactive effect of temperature and humidity levels on the relative increase in polarization resistance of LSCF cathodes that is caused by humidity. With regards to stability, PNNL found that $3 \%$ water in the cathode air caused increased degradation in LSCF at temperatures below $700-750^{\circ} \mathrm{C}$ and decreased degradation at higher temperatures. Georgia Institute of Technology found that LSCF cathodes tested for 30 hours at $750^{\circ} \mathrm{C}$ did not exhibit degradation. The University of Maryland and Georgia Institute of Technology agree that water adsorption plays a role in the impact water has upon LSCF cathodes. Regarding effects on composition and microstructure, Georgia Institute of Technology indicated that humidity leads to increased Sr or Co segregation in LSCF cathodes while PNNL found that during operation at $700^{\circ} \mathrm{C}$, humidity affects the rate of compositional evolution of minor iron cobalt spinel phases present in the cathode and accelerates the growth of nano-nodules that formed on the surfaces of LSCF cathodes that were operated at temperatures less than $750^{\circ} \mathrm{C}$. NETL and Georgia Institute of Technology recommend infiltration as a possible means of mitigating the effects of humidity on LSM/YSZ and LSCF cathodes, respectively.

\section{Acknowledgements}

The work summarized in this report was funded through the Solid-state Energy Conversion Alliance (SECA) Core Technology Program by the U.S. Department of Energy's Office of Fossil Energy. 
Figures

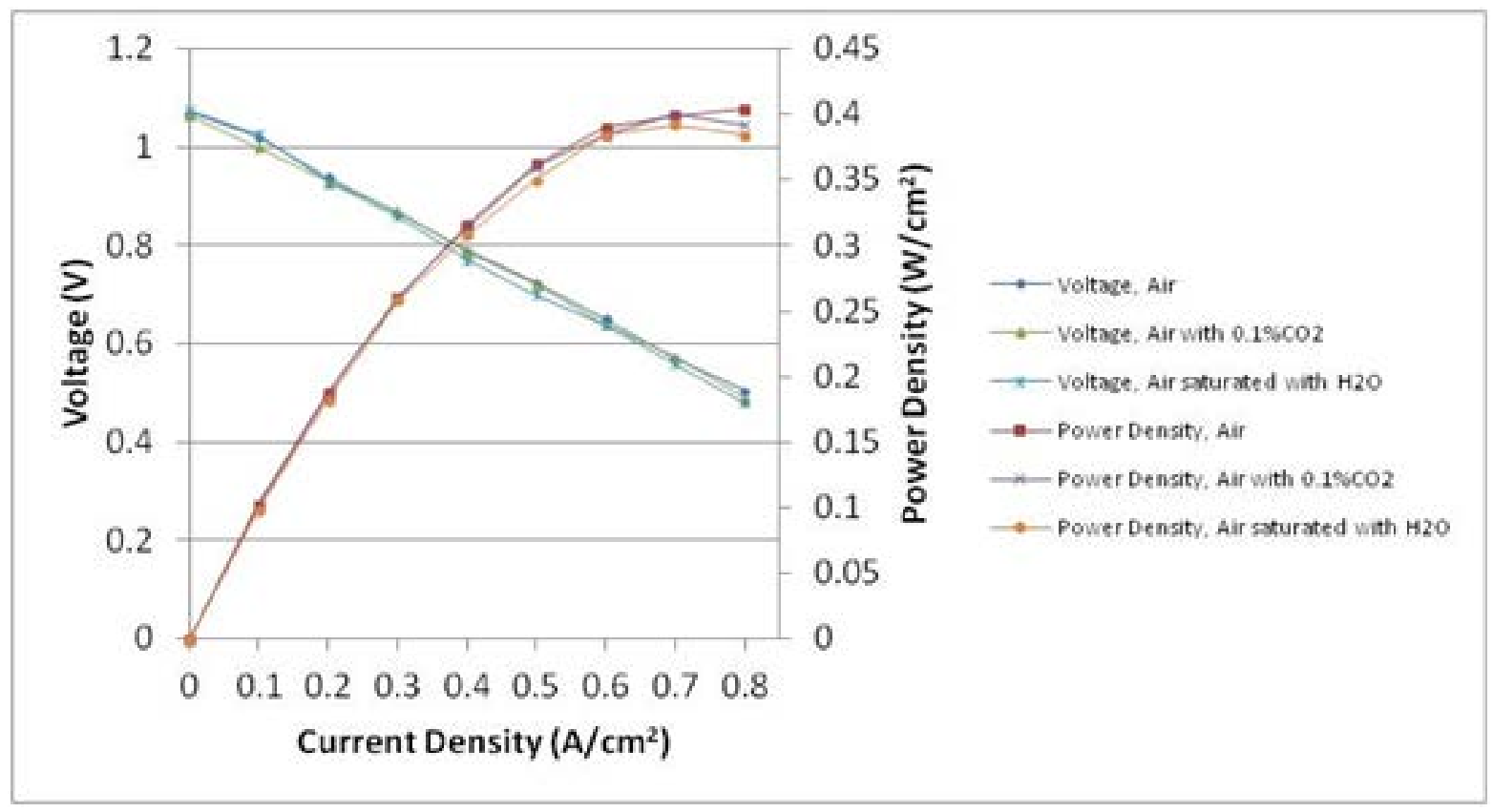

Figure 1. Single cell stack performance with different cathode air compositions (University of Connecticut).

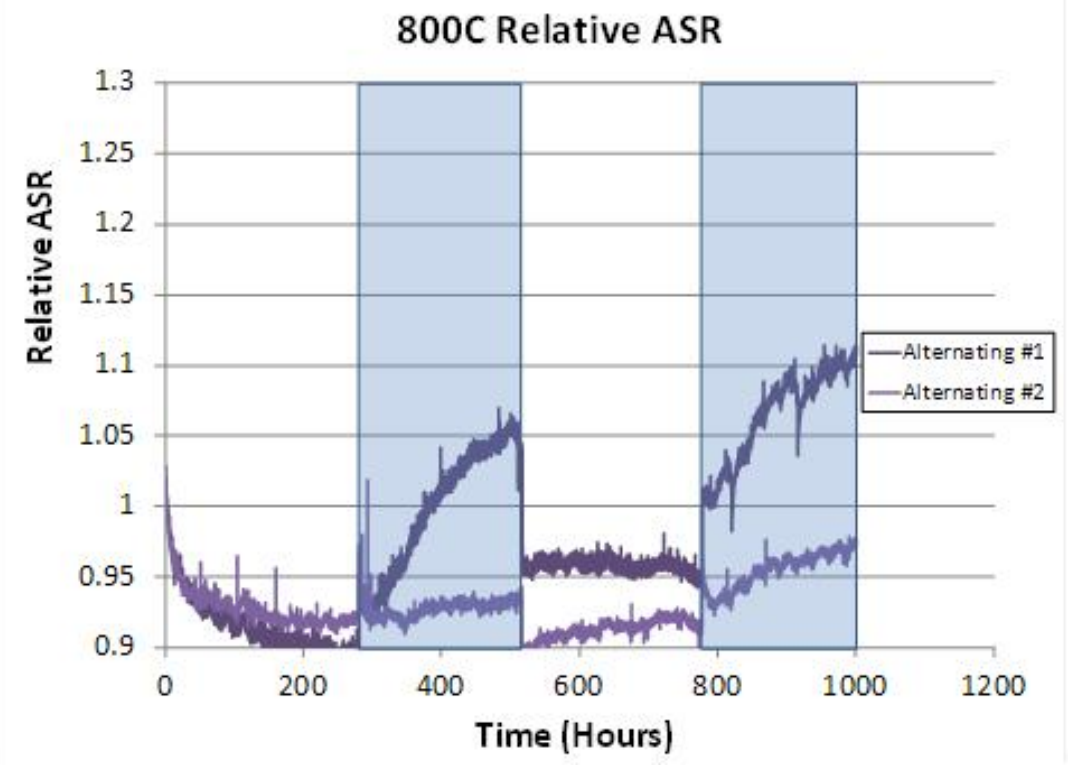

(a) 


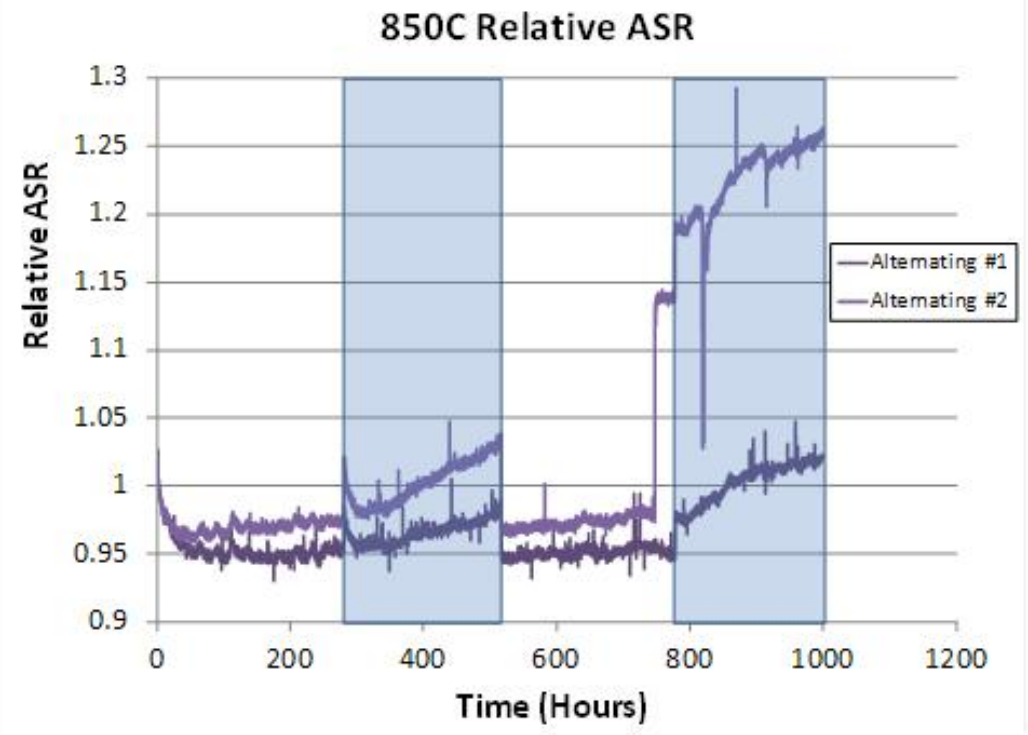

(b)

Figure 2. ASR of cells operated at (a) $800^{\circ} \mathrm{C}$ and (b) $850^{\circ} \mathrm{C}$ in air in which the water concentration was alternated between $0 \%$ (unshaded regions) and 3\% (regions shaded in blue) (PNNL).

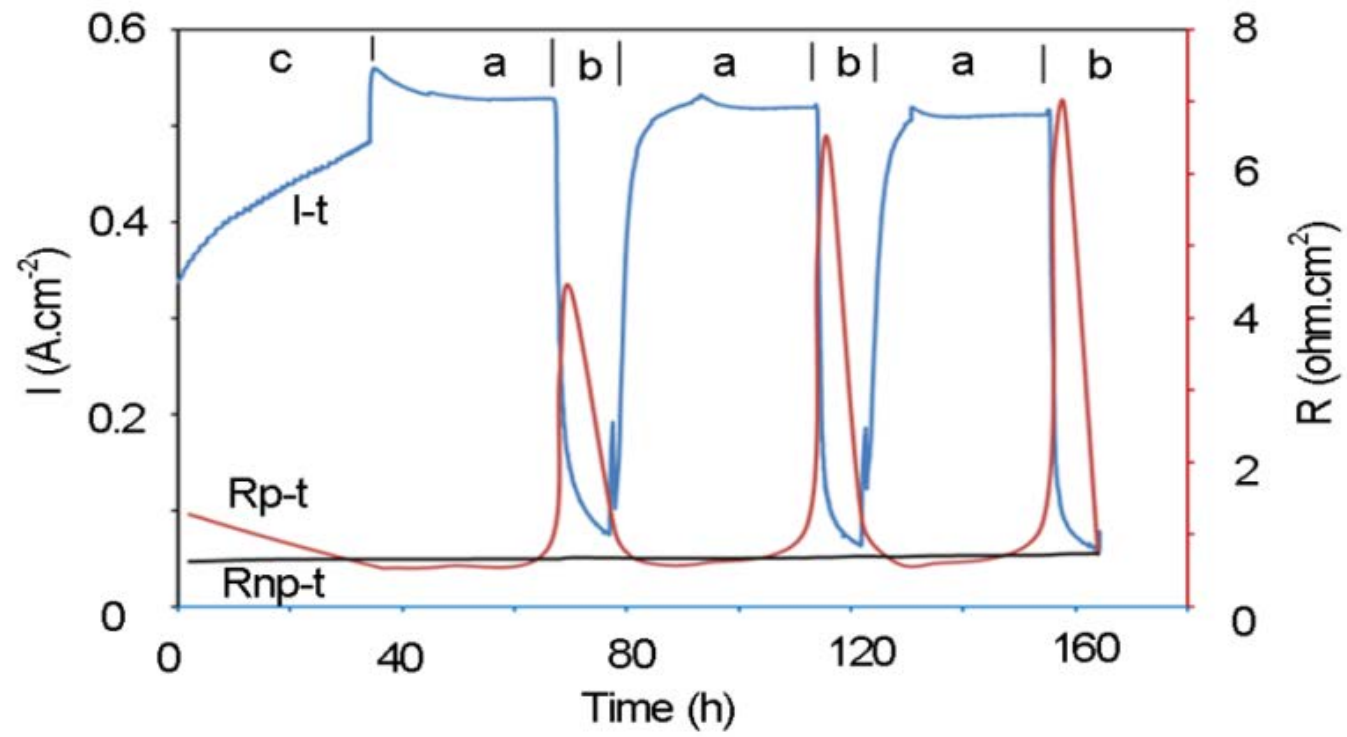

Figure 3. I-t and R-t curves of LSM/YSZ/LSM symmetrical cells tested in 3\% $\mathrm{H}_{2} \mathrm{O}$-air, dry air (a), and $20 \% \mathrm{H}_{2} \mathrm{O}$-air (b) at $1123 \mathrm{~K}$ with $0.5 \mathrm{~V}$ bias. Rp: polarization resistance, Rnp: nonpolarization resistance (University of Connecticut). 


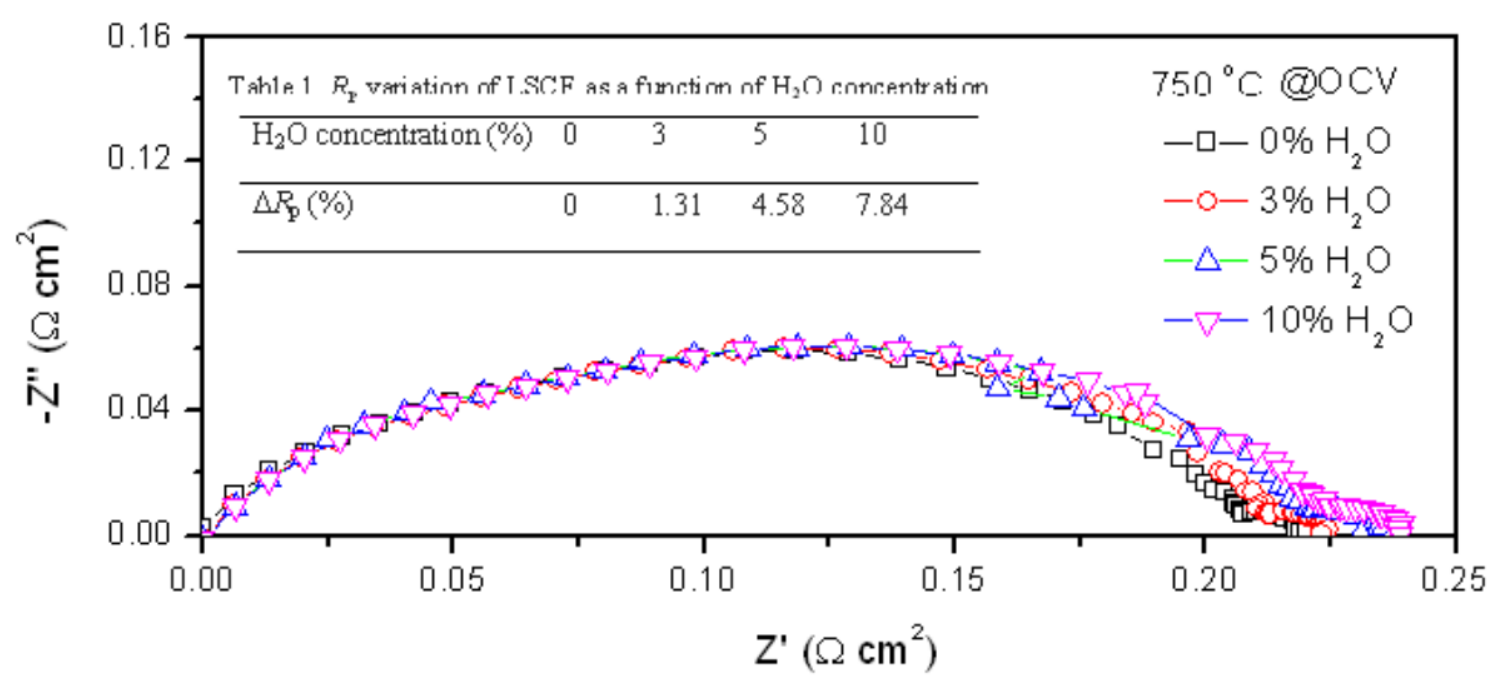

Figure 4. The impedance spectra of the LSCF cathode in humidified air with different concentrations of water vapor $(0,3,5$, and $10 \%)$ under $\mathrm{OCV}$ at $750^{\circ} \mathrm{C}$ (Georgia Institute of Technology).

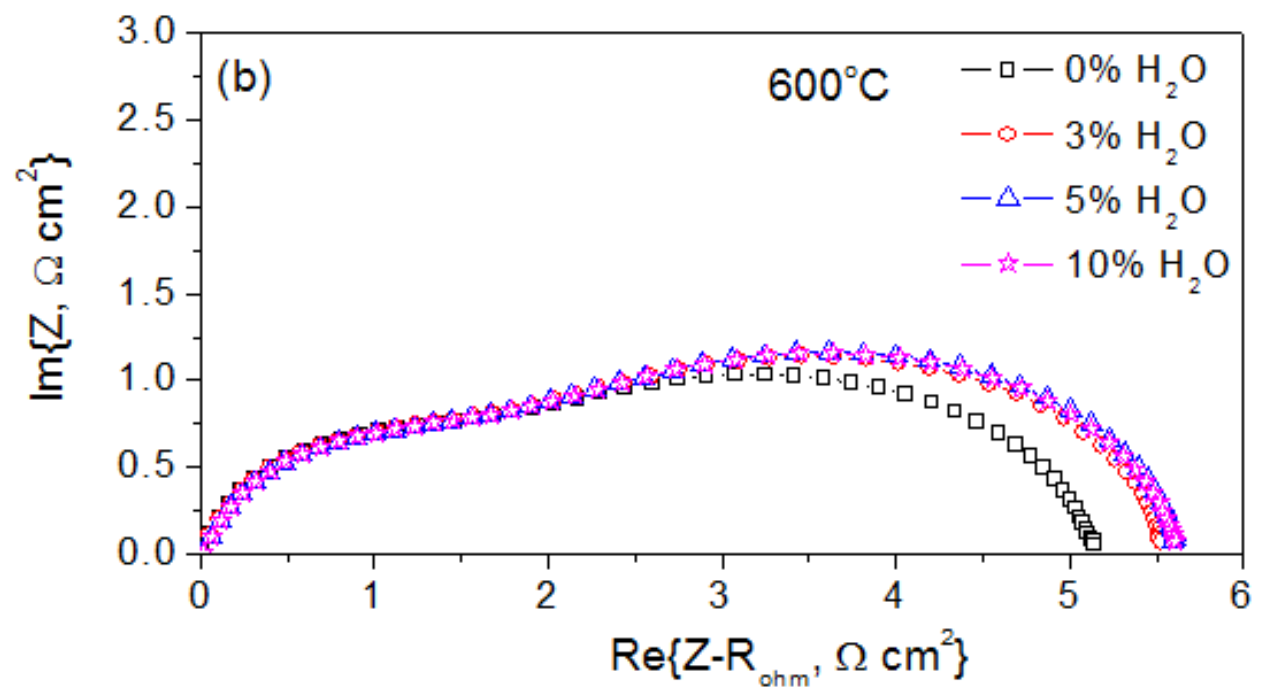

Figure 5. The impedance spectra of the porous LSCF cathode in humidified air with different concentrations of water vapor $(0,3,5$, and $10 \%)$ under $\mathrm{OCV}$ at $600^{\circ} \mathrm{C}$ (Georgia Institute of Technology). 


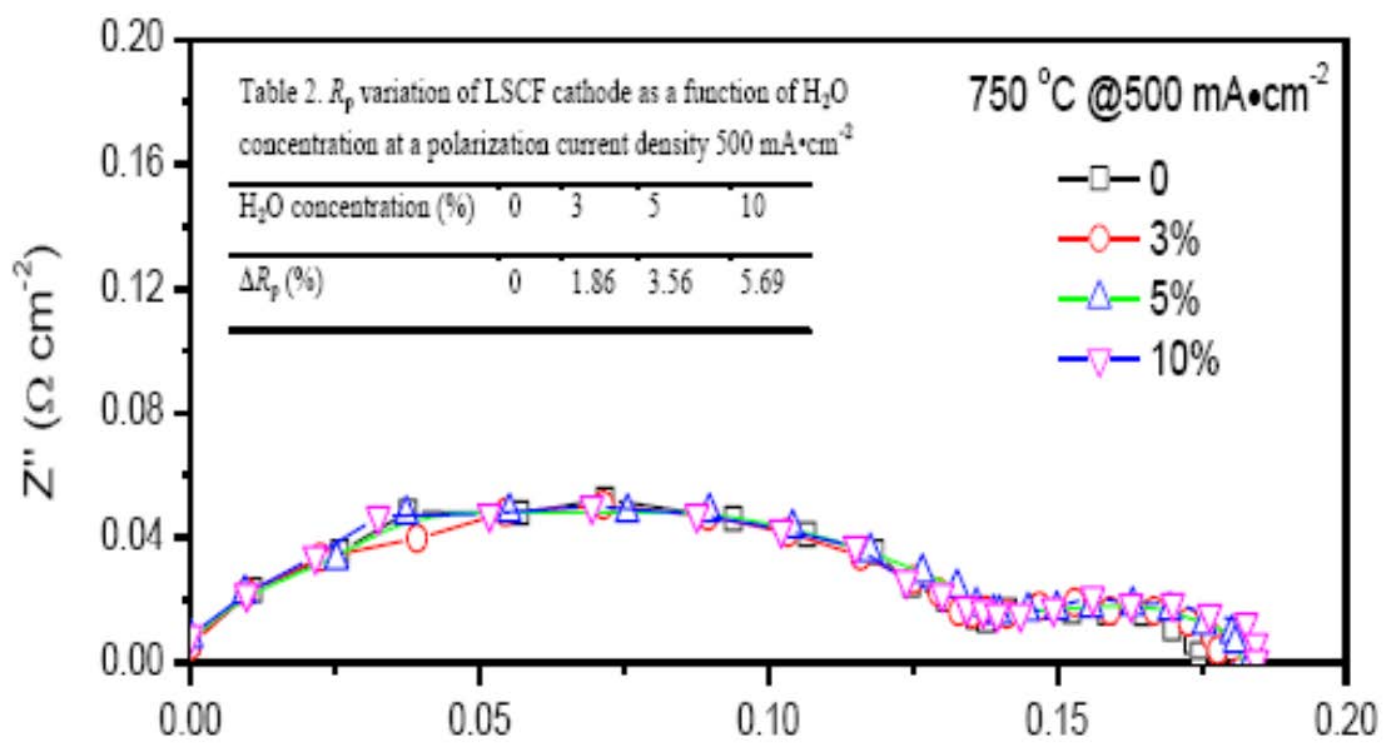

Figure 6. Impedance spectra of LSCF in air with various water vapor concentrations $(0,3 \%, 5 \%$ and $10 \%$ ) at a cathodic current density of $500 \mathrm{mAcm}-2$ at $750^{\circ} \mathrm{C}$ (Georgia Institute of Technology).

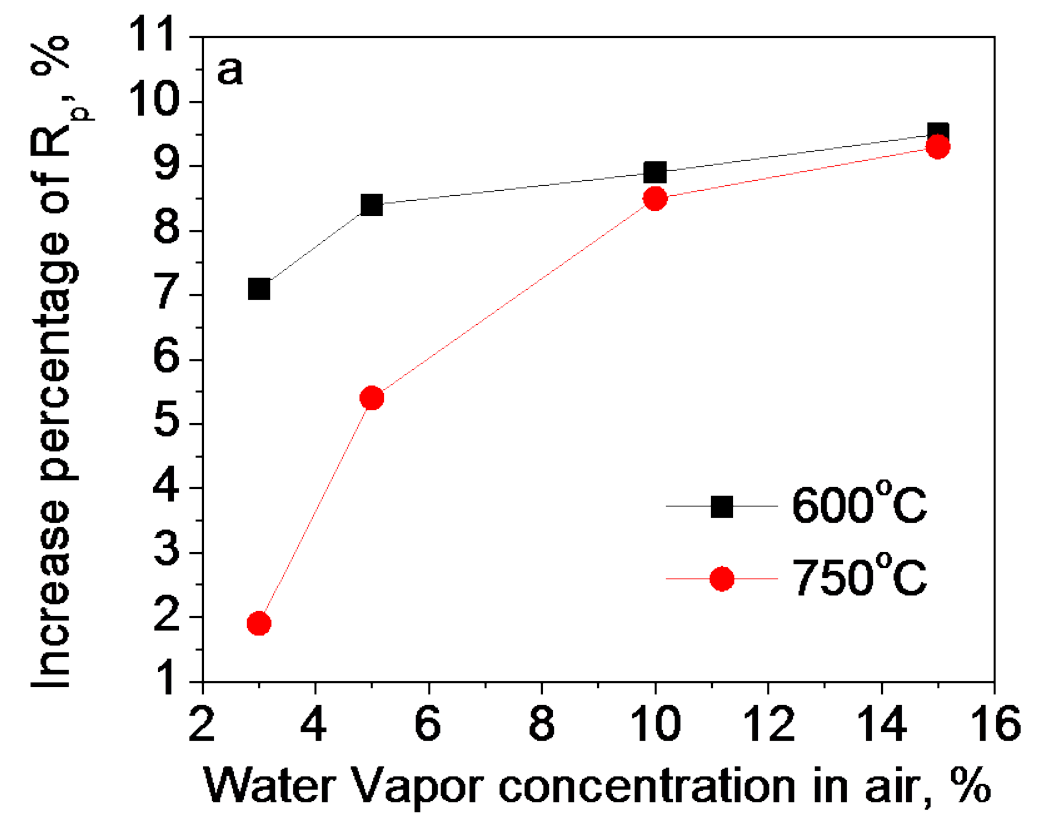

Figure 7. Dependence of LSCF cathode polarization resistance on the concentration of $\mathrm{H}_{2} \mathrm{O}$ (Georgia Institute of Technology). 

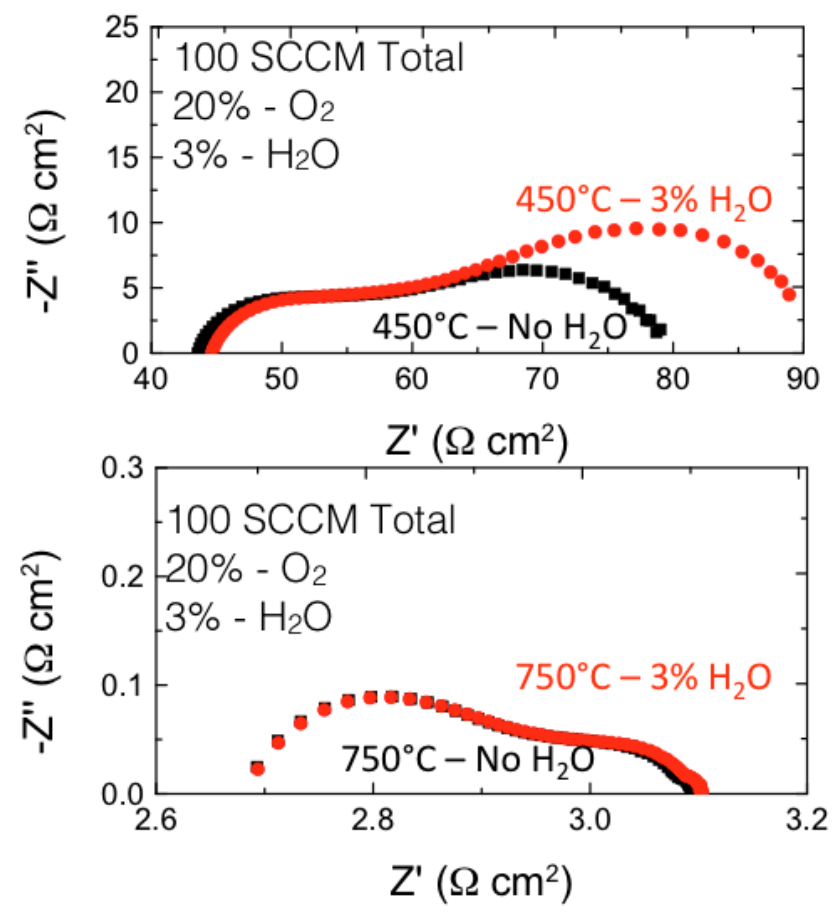

Figure 8. $\mathrm{H}_{2} \mathrm{O}$ effect on LSCF-GDC symmetric cell EIS at $450^{\circ} \mathrm{C}$ and $750^{\circ} \mathrm{C}$ (University of Maryland).

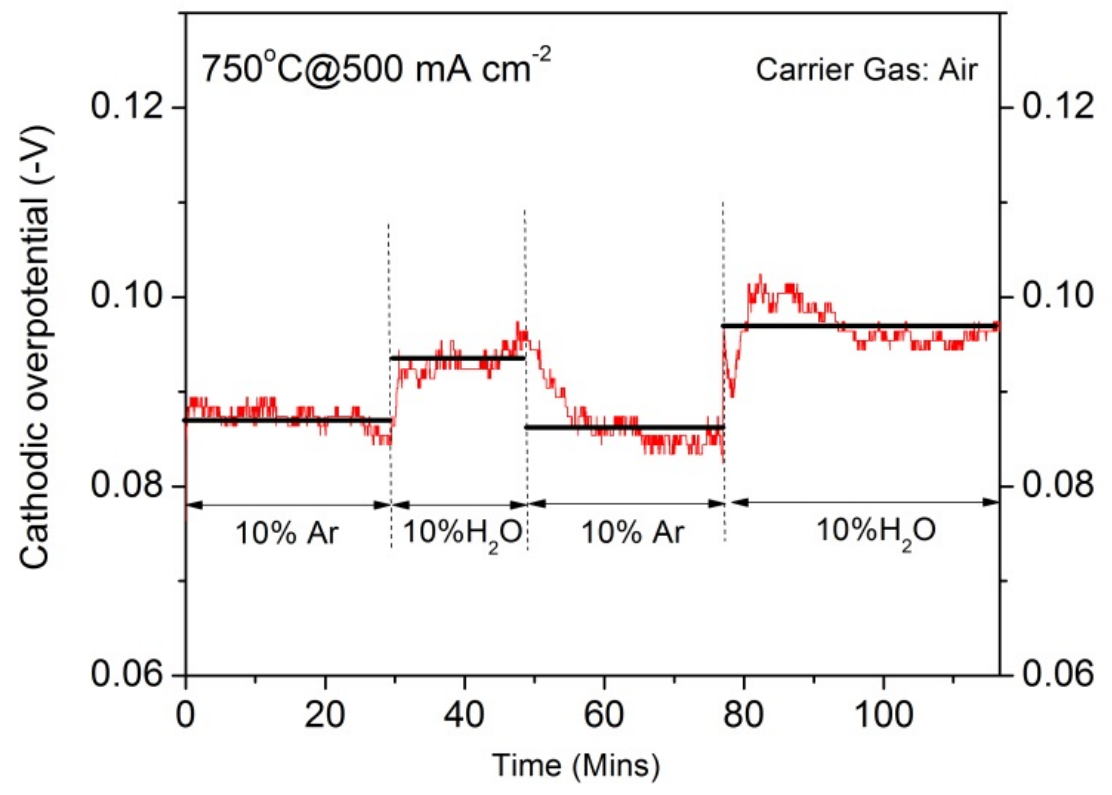

Figure 9. Overpotential of LSCF in air with $10 \% \mathrm{H}_{2} \mathrm{O}$ at $750^{\circ} \mathrm{C}$ (Georgia Institute of Technology). 


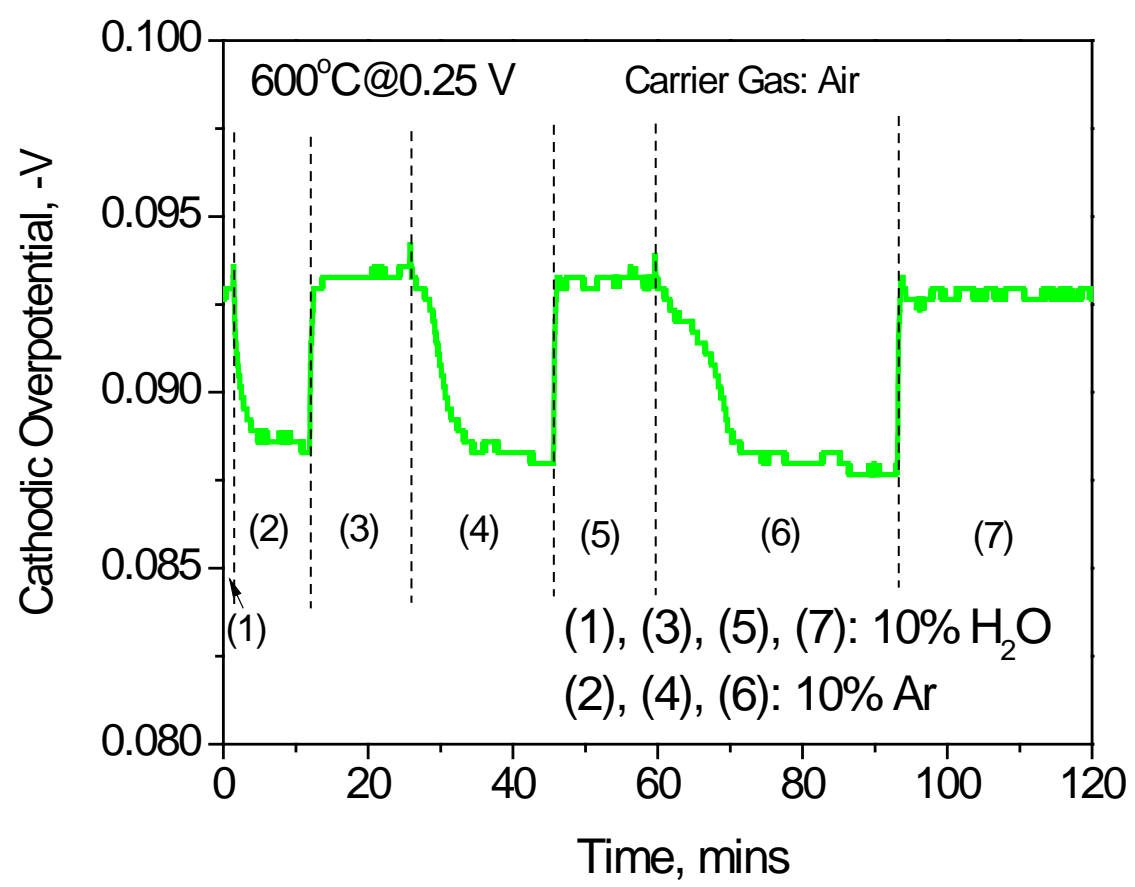

Figure 10. Overpotential of an LSCF cathode in air with switching between $10 \%$ argon and water vapor under a constant voltage of $0.25 \mathrm{~V}$ at $600^{\circ} \mathrm{C}$ (Georgia Institute of Technology).
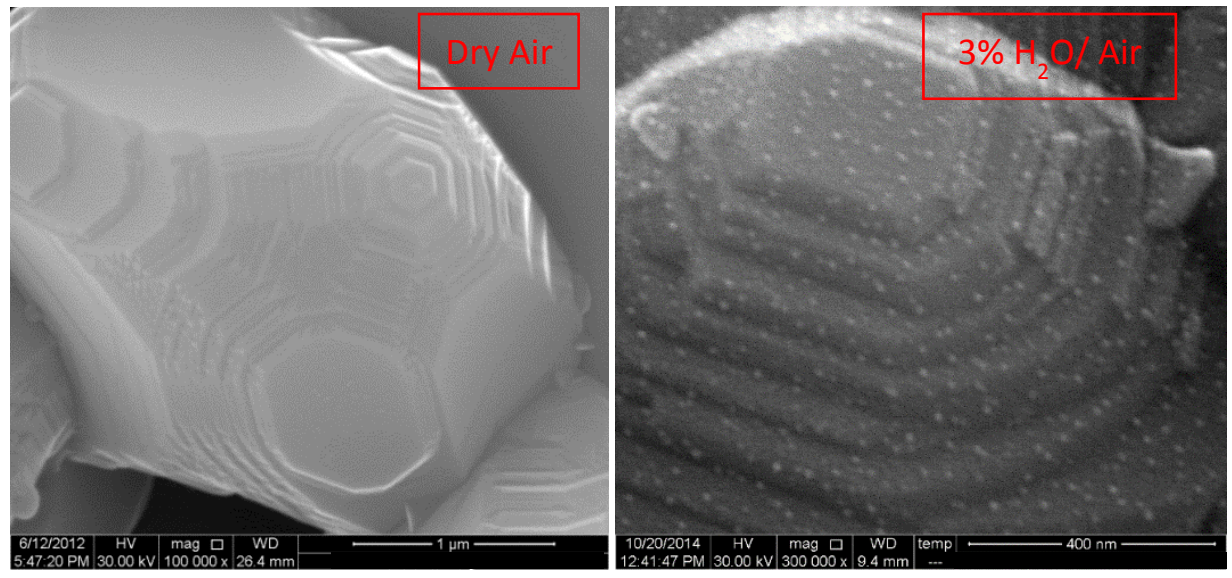

Figure 11. Surface morphology of LSM cathode tested (LSM/YSZ/LSM symmetric cell) in dry air and $3 \% \mathrm{H}_{2} \mathrm{O} /$ Air at $850^{\circ} \mathrm{C}$ and $0.5 \mathrm{~V}$ for 100 hours (University of Connecticut). 


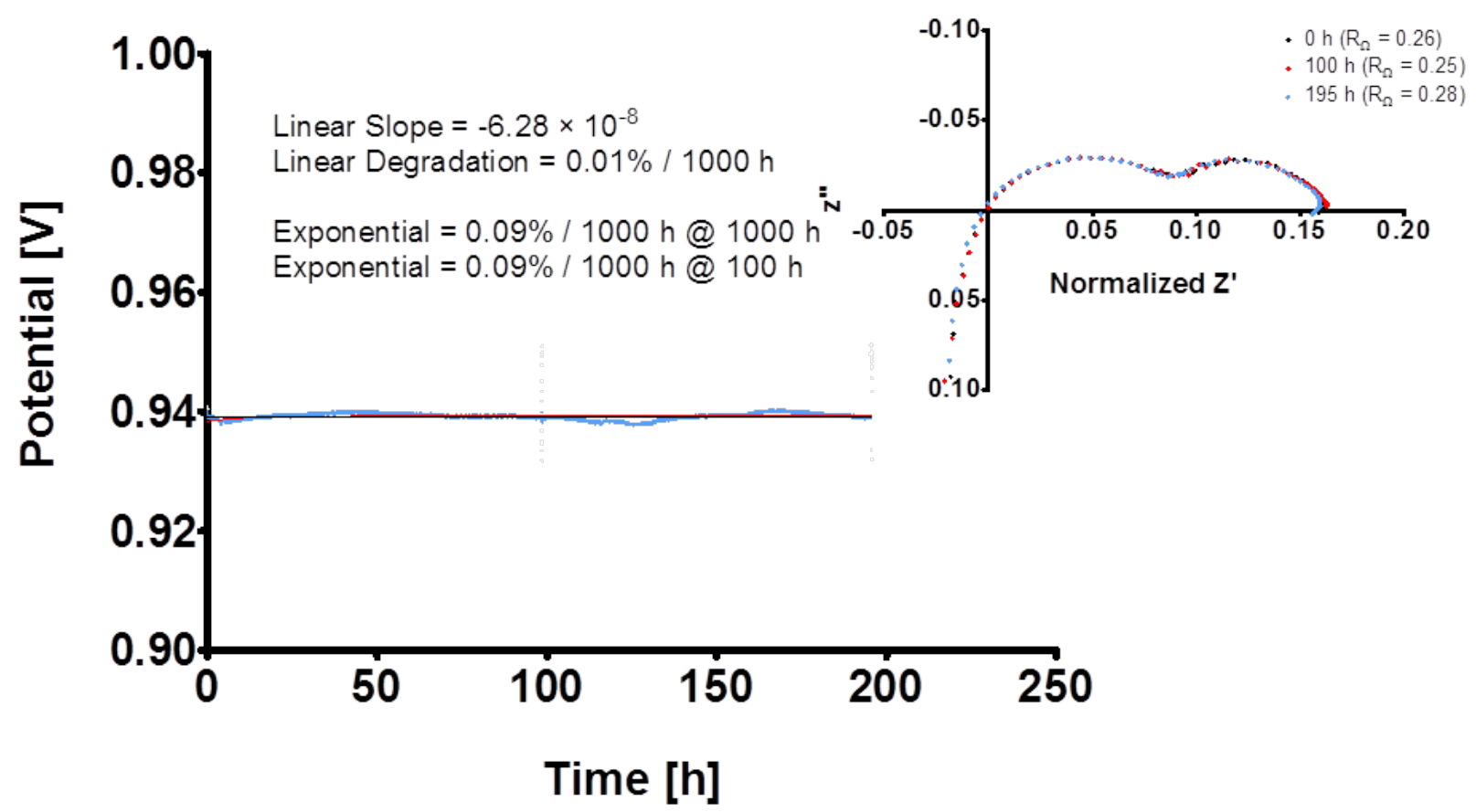

Figure 12. Example voltage and EIS trace for $10 \%$ steam at low current density $\left(0.25 \mathrm{~A} / \mathrm{cm}^{2}\right)$ (NETL).

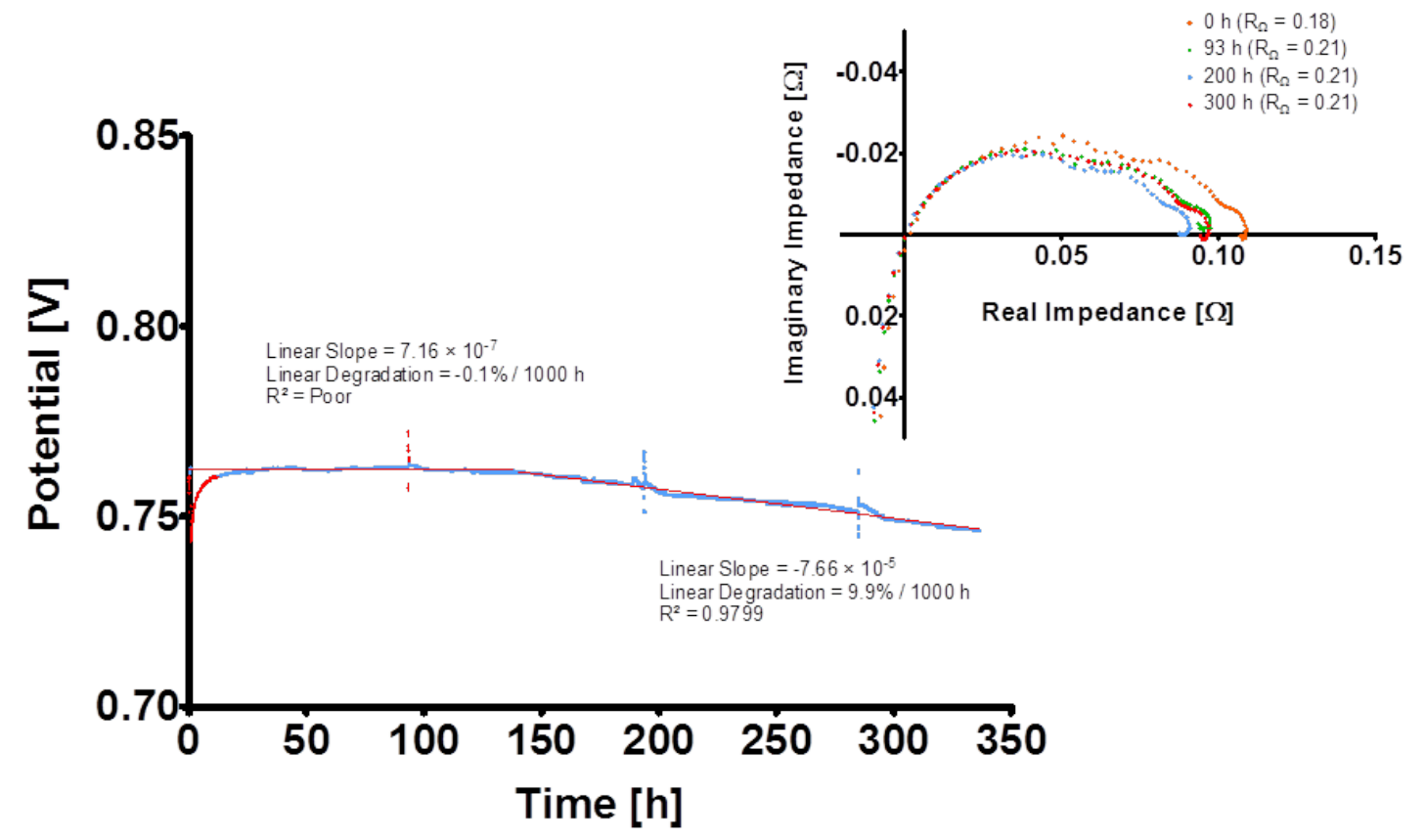

Figure 13. Example voltage and EIS trace for $10 \%$ steam at high current density $\left(0.75 \mathrm{~A} / \mathrm{cm}^{2}\right)$ (NETL). 


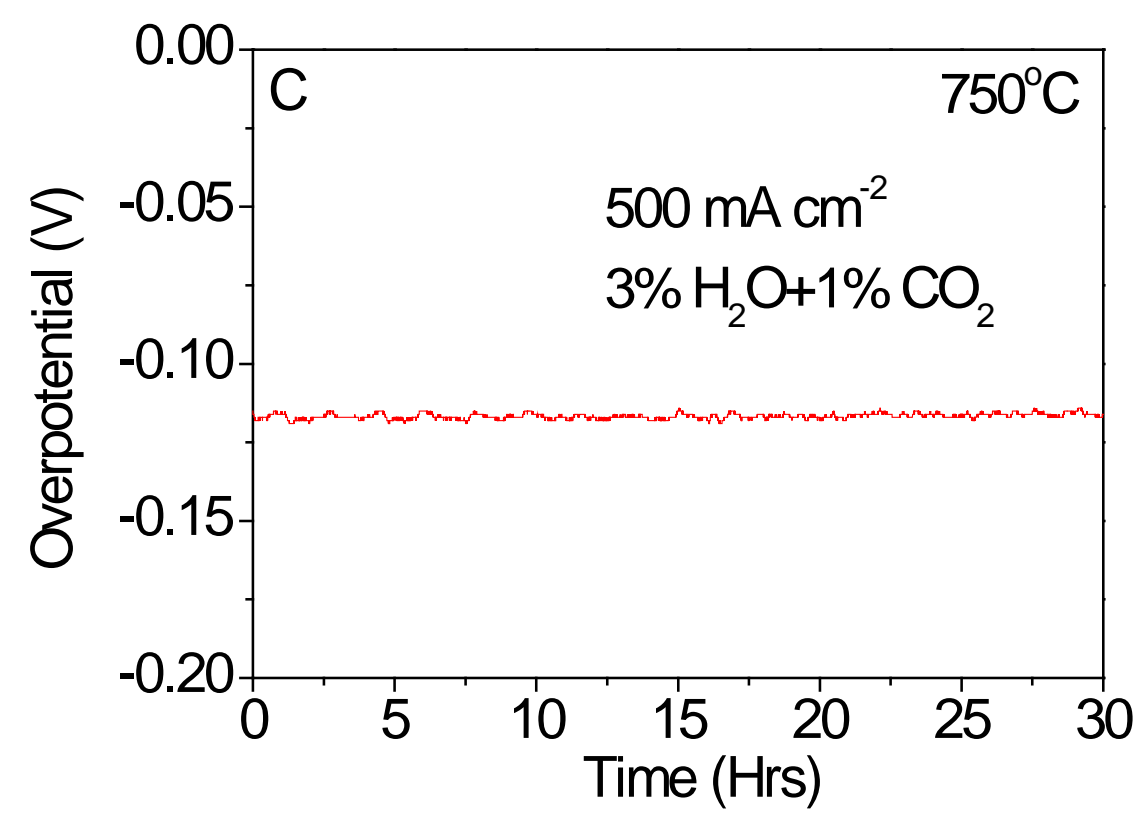

Figure 14. Overpotential of an LSCF cathode as a function of time when exposed to air with $3 \%$ $\mathrm{H}_{2} \mathrm{O}$ and $1 \% \mathrm{CO}_{2}$ tested at $750^{\circ} \mathrm{C}$ (Georgia Institute of Technology).
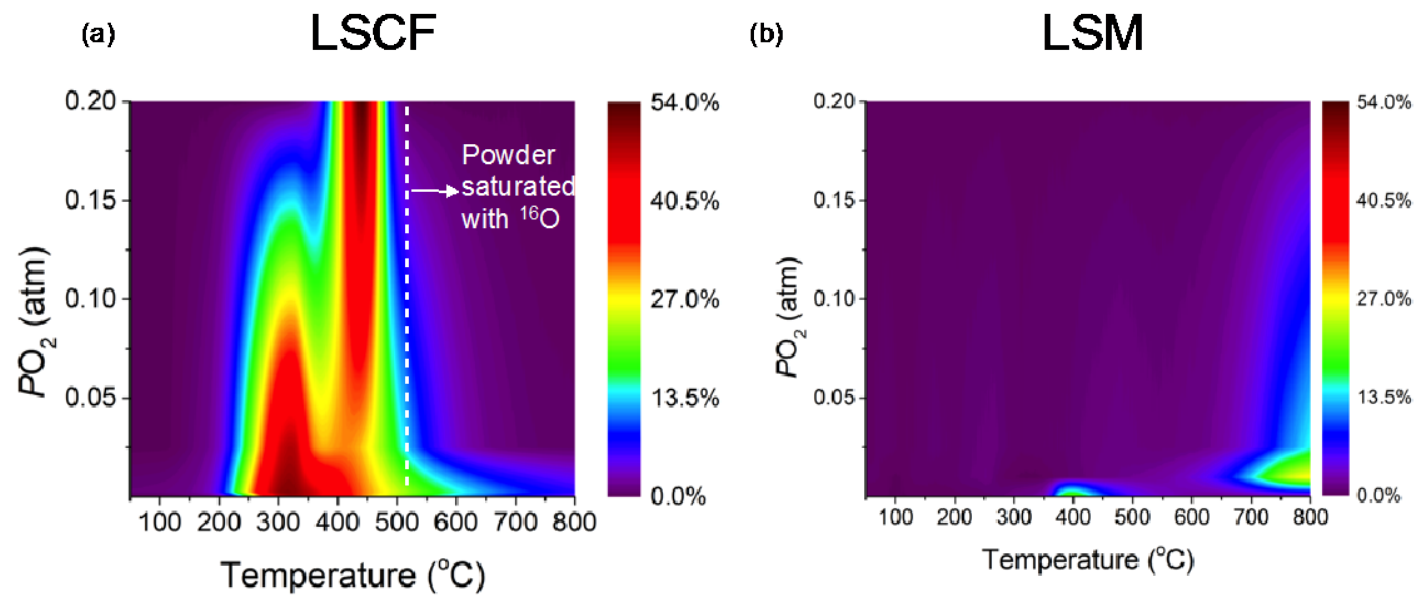

Figure 15. Contour plots of $\mathrm{H}_{2} \mathrm{O}$ exchange with (a) $\mathrm{LSCF}$ and (b) $\mathrm{LSM}$ as a function of $\mathrm{pO}_{2}$ and temperature, from temperature programmed exchange experiments (University of Maryland). 

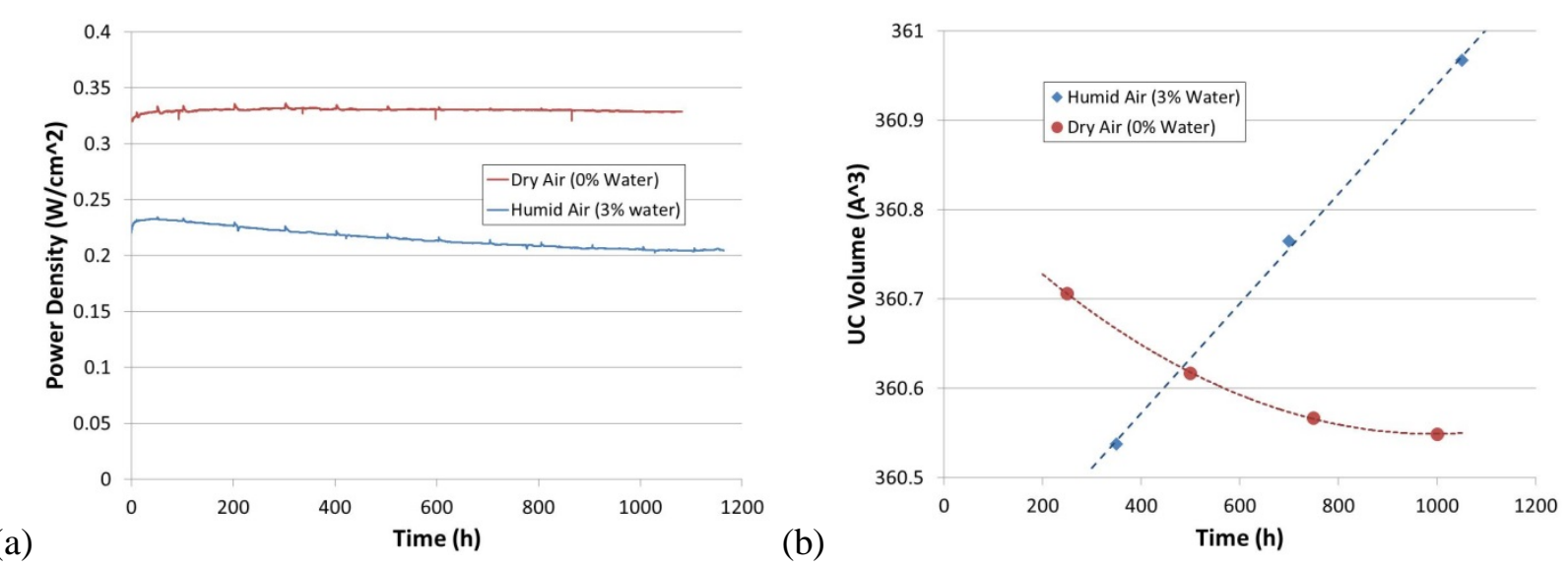

Figure 16. In-operando XRD data from LSM/YSZ button cells tested including (a) the power density and (b) unit cell volume of LSM in the cathode (PNNL).
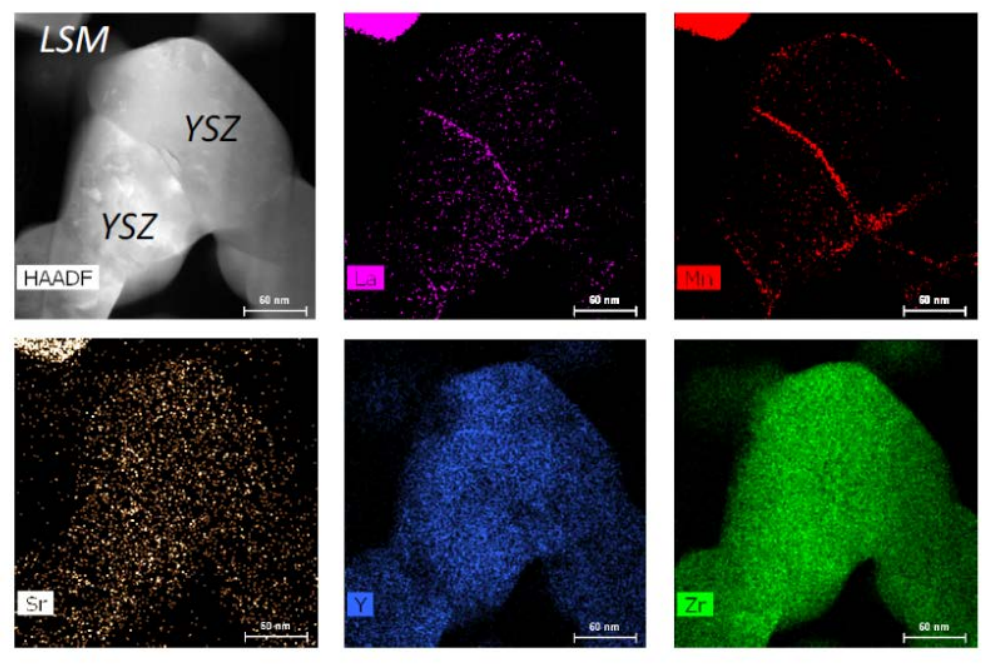

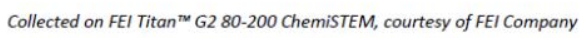

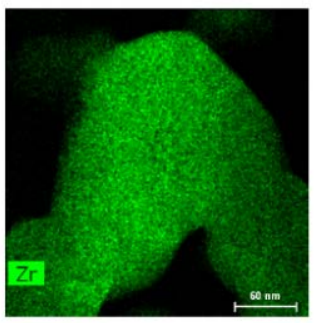

Figure 17. TEM-EDS results demonstrating the segregation of La and Mn cations to the YSZ grain boundary (University of Maryland). 

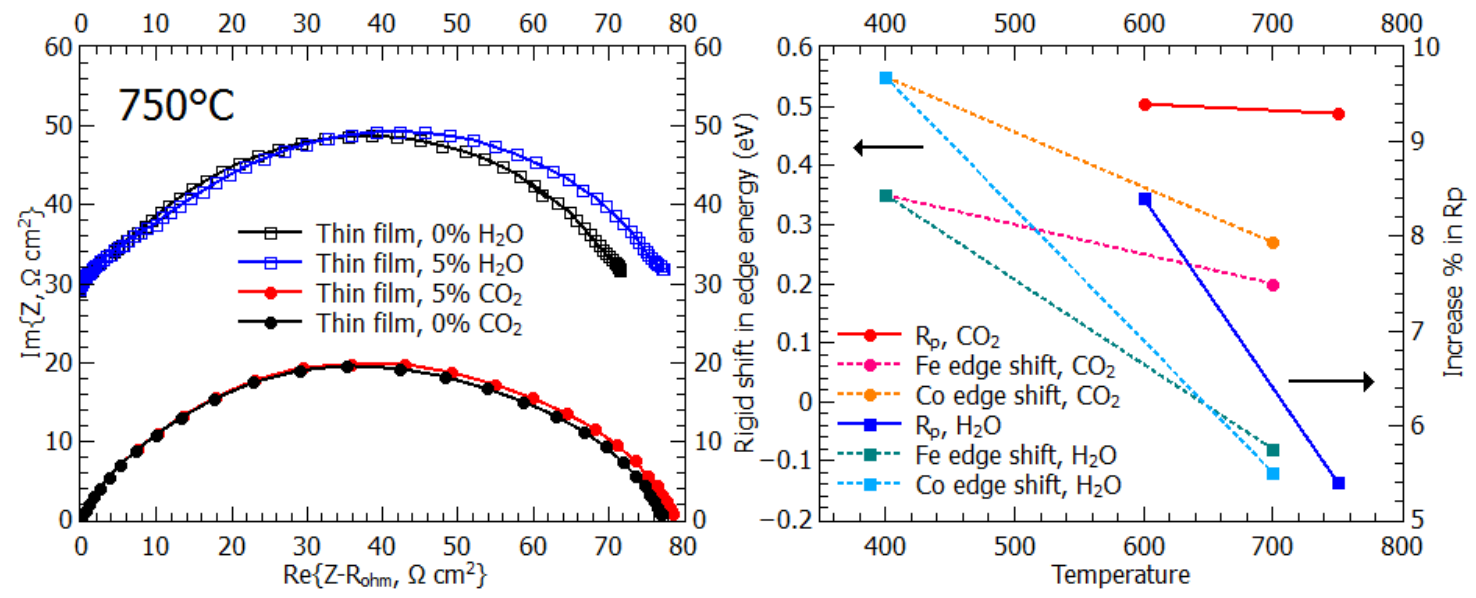

Figure 18. (a) Impedance spectra of a porous LSCF cathode, showing the increase in polarization resistance due to exposure to $\mathrm{H}_{2} \mathrm{O}$ and $\mathrm{CO}_{2}$. (b) The correlation between electrochemical performance, operating conditions, and rigid shifts in absorption edge energy (Georgia Institute of Technology).

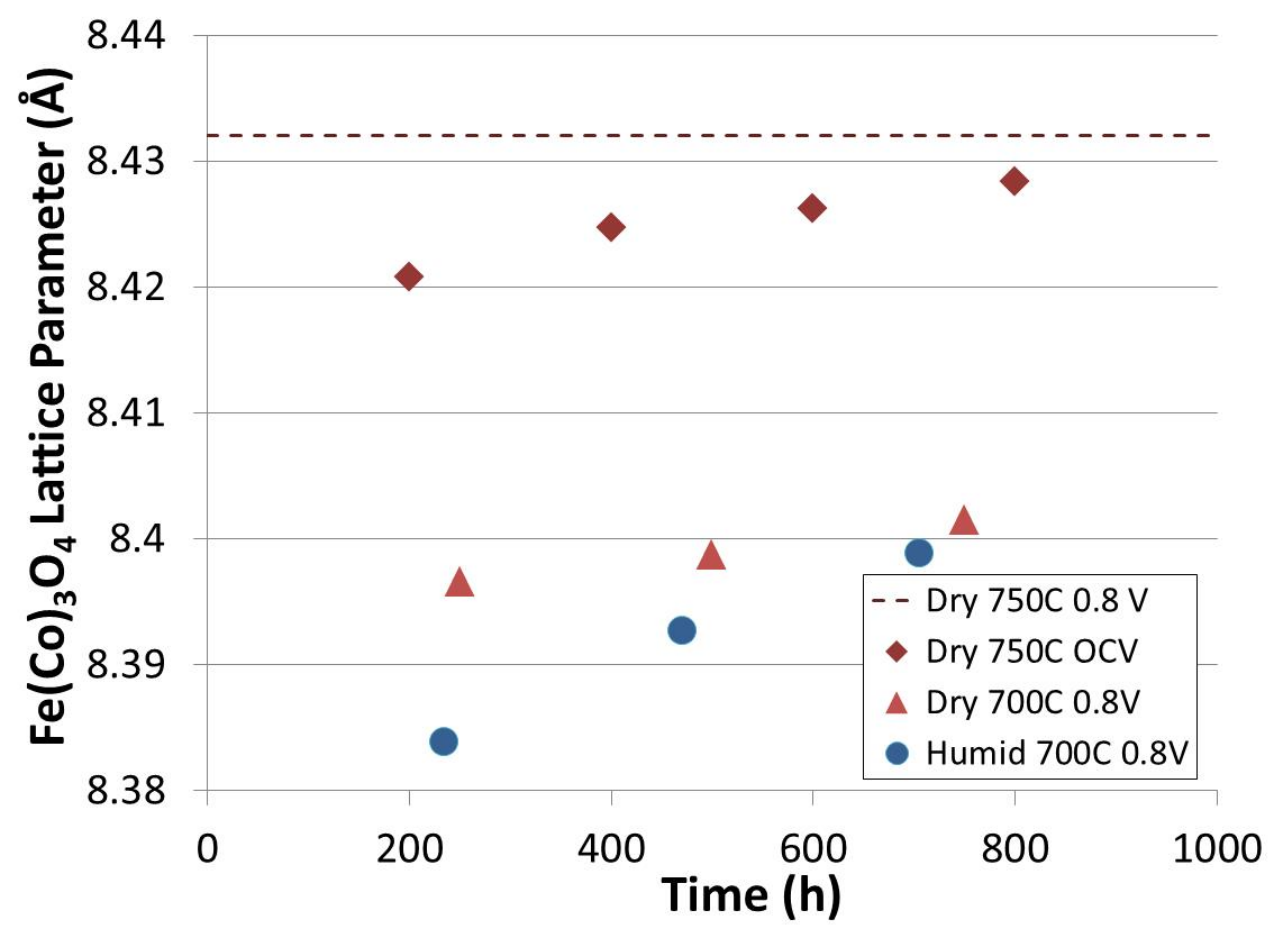

Figure 19. Cubic lattice parameter of Fe-rich iron cobalt spinel as a function of time as determined by Rietveld refinement of in-operando XRD patterns (PNNL). 
(a)
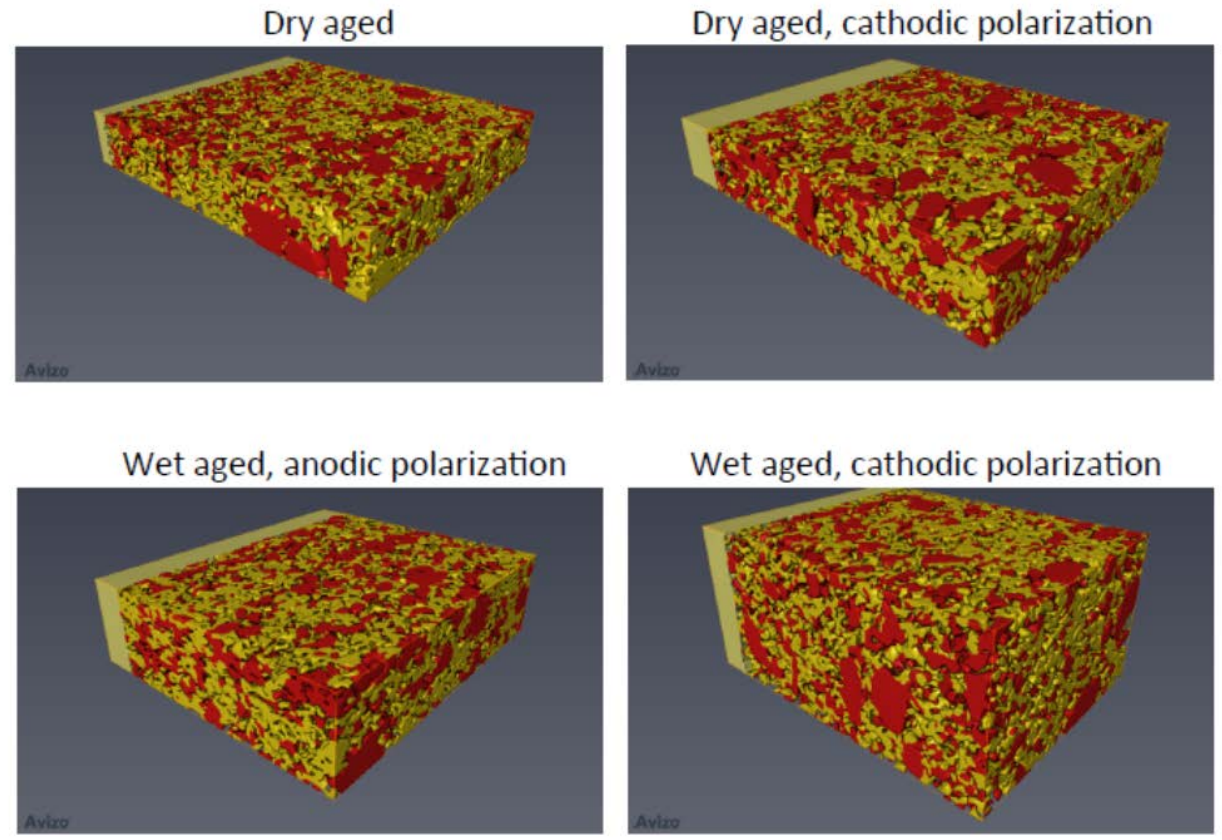

Largest 5 connected components

(b)

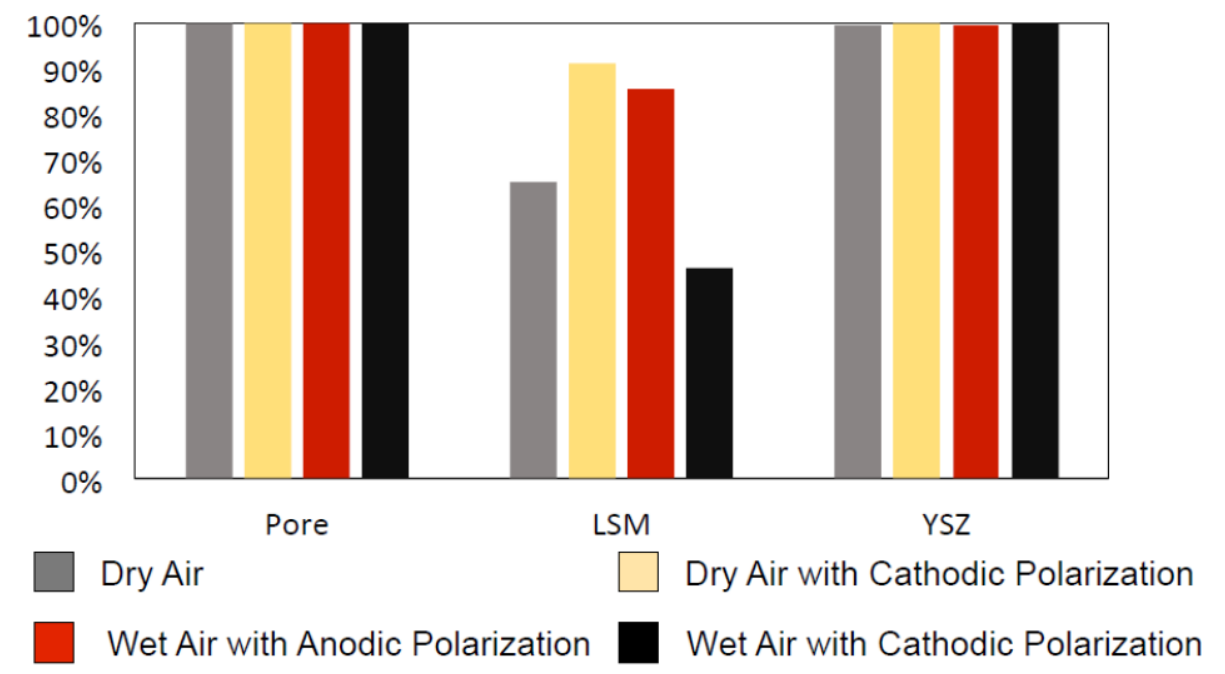

Figure 20. (a) Representative visualizations of four LSM/YSZ composite cathodes reconstructed by FIB-SEM. The LSM phase is red and YSZ is yellow. The pore phase is excluded from this visualization for clarity. (b) Summary of connected network after phase skeletonization. The value plotted is the percentage of the total network length that is contained in the 5 largest components. The pore and YSZ networks are $100 \%$, meaning the phases are fully percolated, while the LSM phase has many more isolated particles (University of Maryland). 


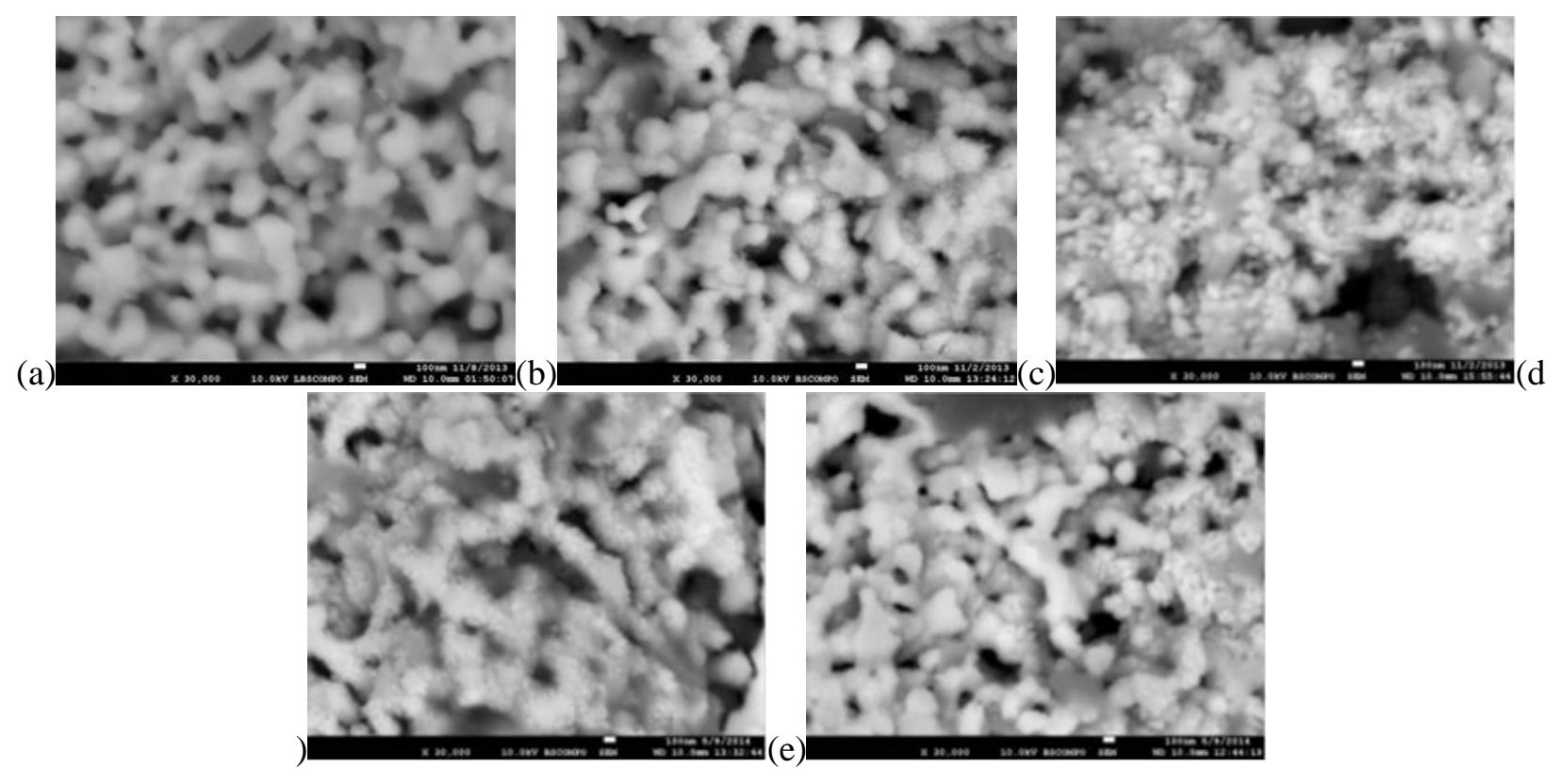

Figure 21. SEM images of fracture surfaces of LSCF cathodes after (a) sintering but no electrochemical testing, (b) $\sim 1000 \mathrm{~h}$ of testing at $650^{\circ} \mathrm{C}$ in dry air, (c) $\sim 1000 \mathrm{~h}$ of testing at $650^{\circ} \mathrm{C}$ in air with $3 \%$ water vapor, (d) $\sim 1000 \mathrm{~h}$ of testing at $700^{\circ} \mathrm{C}$ in dry air, (e) $\sim 1000 \mathrm{~h}$ of testing at $700^{\circ} \mathrm{C}$ in air with $3 \%$ water vapor (PNNL).

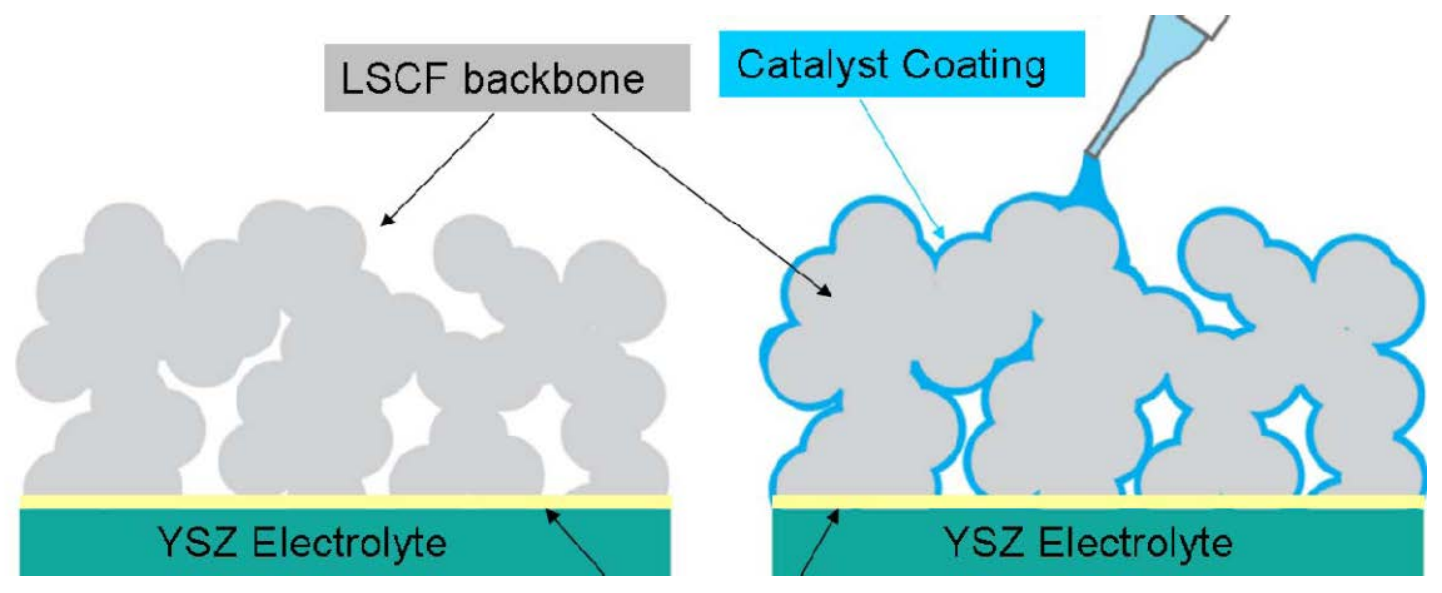

Figure 22. A schematic of a catalyst coating on the surface of the LSCF cathode fabricated through infiltration (Georgia Institute of Technology). 